MINERALOGIA POLONICA

DOI 10.2478/v10002-007-0025-6

PL ISSN 0032-6267

Vol. 38, No 2, 2007

Zdzisław M. MIGASZEWSKI ${ }^{1}$, Ewa STARNAWSKA², Agnieszka GAEUSZKA ${ }^{1}$

\title{
GORCEIXITE FROM THE UPPER CAMBRIAN ROCKS OF THE PODWIŚNIÓWKA MINE PIT, HOLY CROSS MOUNTAINS (SOUTH-CENTRAL POLAND)
}

\author{
Received April 07, 2007; accepted June 02, 2007
}

Abstract. This report presents the results of a petrographical, mineralogical (SEM/EDS, XRD) and geochemical (XRF, CV-AAS, ICP-MS) study of gorceixite (barium aluminophosphate) from the abandoned Podwiśniówka mine pit. This site is highlighted by the presence of highly acidic pit pond whose chemistry is strongly affected by the exposed pyrite-bearing zone. The gorceixite occurs in the Upper Cambrian carbonaceous clayey shales, quartzites and tuffs in form of minute accumulations varying from about 0.5 to $100 \mu \mathrm{m}$ in diameter. These accumulations infill voids, cavities, cracks and partly fissures in the rocks examined. The other minerals of the crandallite series, i.e. florencite and goyazite, can be found only in trace amounts. The gorceixite-bearing rocks, especially carbonaceous clayey shales, are characterized by the highest concentrations of REE reaching $455.09 \mathrm{mg} \cdot \mathrm{kg}^{-1}$. In addition, these rocks are distinctly enriched in light rare earth elements (LREE), with the $\mathrm{La} / \mathrm{Yb}$ ratio ranging from 24.44 through 36.30. Some of the examined gorceixite accumulations are paragenetically linked to the veined pyrite and nacrite. The latter mineral is indicative of crystallization temperatures of about 200 to $300^{\circ} \mathrm{C}$. The coexistence of gorceixite with the veined nacrite or pyrite mineralization and the volcaniclastic rocks, as well as the microtextural features and high concentrations of REE in the gorceixite-bearing parent rocks suggest that this mineral formed as a result of both hydrothermal and volcanic activity in a shallow-marine basin during the late Cambrian.

Key-words: gorceixite, clayey shales, quartzites, volcaniclastic rocks, mineralogical and chemical composition, REE, hydrothermal-volcanic origin, Podwiśniówka, Holy Cross Mts

\section{INTRODUCTION}

Like other secondary aluminophosphate and phosphate minerals, i.e. florencite (REE) $\mathrm{Al}_{3}\left(\mathrm{PO}_{4}\right)_{2}(\mathrm{OH})_{6}$ (Pouliot, Hofmann 1981), crandallite $\mathrm{CaHAl}_{3}\left[\left(\mathrm{PO}_{4}\right)_{2}(\mathrm{OH})_{6}\right]$ (Scott 1987), goyazite $\operatorname{SrHAl}_{3}\left[\left(\mathrm{PO}_{4}\right)_{2}(\mathrm{OH})_{6}\right]$ (Kato, Radoslovich 1968), apatite

${ }^{1}$ Jan Kochanowski University, Institute of Chemistry, Geochemistry and the Environment Div., ul. Chęcińska 5, 25-020 Kielce, Poland; e-mail: zmig@pu.kielce.pl; aggie@pu.kielce.pl

2 Polish Geological Institute, Electron Microscope Laboratory, ul. Rakowiecka 4, 00-975 Warszawa, Poland; e-mail: ewastarn@yahoo.com 
$(\mathrm{Ca}, \ldots)_{5}\left(\mathrm{PO}_{4}, \ldots\right)_{3}(\mathrm{~F}, \mathrm{Cl}, \mathrm{OH})$, xenotime $\mathrm{Y}\left[\mathrm{PO}_{4}\right]$, gorceixite is isostructural (hexagonal) with alunite. It belongs to the crandallite series of aluminum-phosphate-sulphate (APS) minerals, and its chemical formula is differently reported by various authors: $\mathrm{BaAl}_{3}\left(\mathrm{PO}_{4}\right)_{2}(\mathrm{OH})_{5} \cdot \mathrm{H}_{2} \mathrm{O}$ (Dill et al. 1995; Ward et al. 1996; Rasmussen et al. 1998), $\mathrm{BaAl}_{3} \mathrm{H}\left[(\mathrm{OH})_{6}\left(\mathrm{PO}_{4}\right)_{2}\right]$ (Kato, Radoslovich 1968; Dill 2001; Manecki 2004) or $\mathrm{BaAl}_{3}\left(\mathrm{PO}_{4}\right)\left(\mathrm{PO}_{3} \mathrm{OH}\right)(\mathrm{OH})_{6}$ (Dill et al. 2006). Gorceixite is resistant to weathering and dissolves only in strong acids at ambient pressure and temperature of above $400^{\circ} \mathrm{C}$. This mineral is hard (6 in hardness scale), brown, glassy and dull. In general, gorceixite occurs in form of minute crystals $(<0.1$ to $10 \mu \mathrm{m}$ in diameter) infilling vugs, cavities, cracks and fissures in various rocks. The calculations predict that gorceixite is most stable from $\mathrm{pH} 4.0$ to 6.8 (Jerden, Sinha 2006).

Gorceixite was found in a wide range of geochemical environments, including: aluminous metamorphic rocks (Wise 1975), explosive pipe breccias (Ribeiro et al. 2005), weathering mantles developed from apatite-rich carbonatites (e.g., Walter et al. 1995) or basalts (Cabała 2001), hydrothermal barite-fluorite and metal ore veins or alteration zones of porphyry deposits (e.g., Kowalski, Śmietańska 1983; Stoffregen, Alpers 1987), coal seams (e.g., Finkelman, Stanton 1978; Ward et al. 1996), and soils developed from uranium deposits hosted in quartzo-feldspathic gneiss (Jerden, Sinha 2006). This mineral was also discovered in various supergene kaolinite-alunite deposits, i.e. china clay deposits, lateritic duricrusts and karst bauxites (Dill et al. 1995; Putter et al. 2002). In addition, gorceixite and related accessory minerals (florencite, crandallite, goyazite, apatite, xenotime) are also widespread as trace constituents of shallow-marine sandstones of all ages (e.g., Rasmussen et al. 1998). They seem to have been formed in the sulphate-reduction and methanogenesis early-diagenetic zones, probably in association with "reverse weathering" reactions (Rasmussen et al. 1998). According to Rasmussen (1996), these aluminophosphate and phosphate minerals represent an essential global sink for oceanic phosphorus and presumably also for REE. These and other aspects of geology, mineralogy and geochemistry of aluminum phosphates and sulphates of the alunite supergroup (APS minerals) were summarized by Dill (2001).

Gorceixite has not been reported in previous mineralogical studies in the Holy Cross Mountains. Of the aluminophosphate and phosphate minerals of the Wiśniówka mining area, only wavellite $\mathrm{Al}_{3}\left[(\mathrm{OH}, \mathrm{F})_{3} \mid\left(\mathrm{PO}_{4}\right)_{2}\right] \cdot 5 \mathrm{H}_{2} \mathrm{O}$ and variscite $\mathrm{Al}\left[\mathrm{PO}_{4}\right] \cdot 2 \mathrm{H}_{2} \mathrm{O}$ have been described in more detail. According to Dumańska-Słowik et al. (2007), the former mineral completed the crystallization of hydrothermal veined quartz, while the variscite formed later in hypergenic conditions. Moreover, these authors suggested that aluminum and phosphorus might have been generated from degrading detritic feldspars and authigenic apatite or from end-products of mafic intrusions (diabase and lamprophyre) of late Paleozoic age.

This report presents the results of an optical microscope, scanning electron microscope coupled with an energy dispersive X-ray spectrometer (SEM/EDS) and X-ray diffractometer (XRD) study performed on the gorceixite and subordinate florencite and goyazite that occur in the rocks of the abandoned Podwiśniówka mine pit (Fig. 1). The scope of this investigation also encompassed chemical analyses (XRF, ICP-MS, AAS) of gorceixite-bearing rock samples. It should be stressed that the study of gorceixite is 


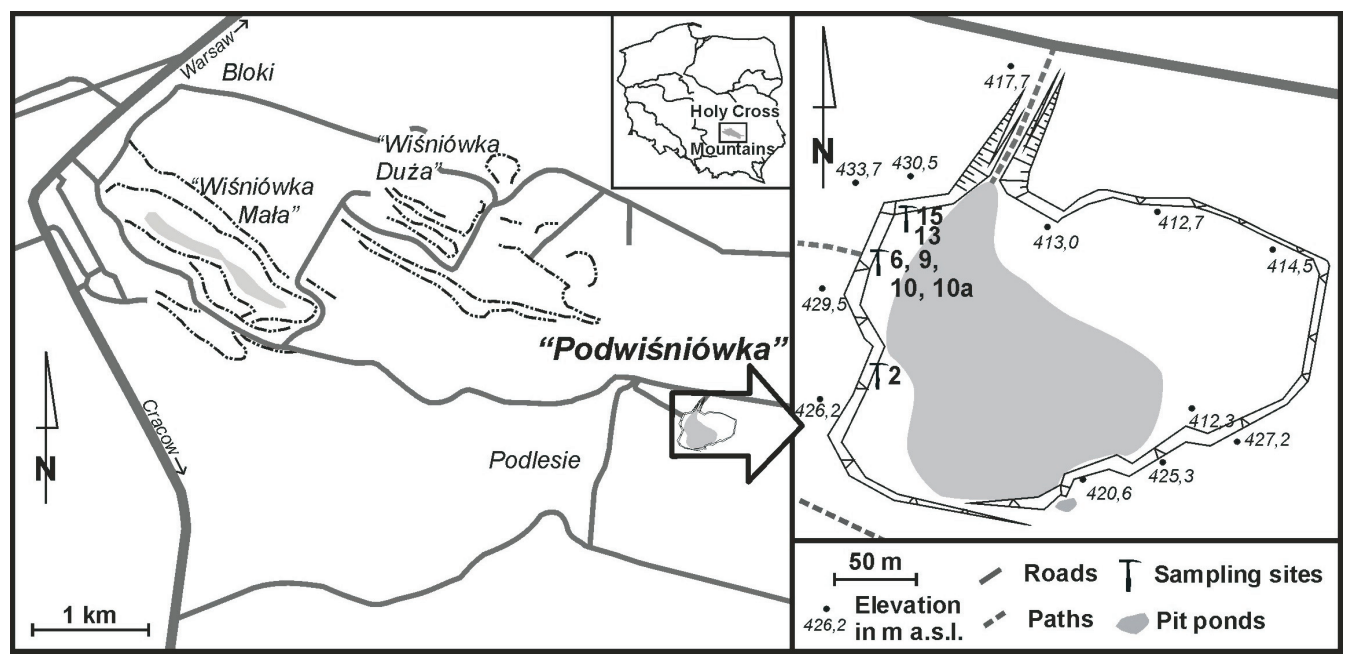

Fig. 1. Localization of the abandoned Podwiśniówka mine pit with an acidic pond (for detailed location of sampling sites see Fig. 2A)

a part of a larger ongoing environmental investigation that includes complex isotope and element determinations of mine pit waters as well as rocks and minerals of the entire mining area (e.g., Migaszewski et al. 2007, 2008).

\section{LOCATION AND CHARACTERIZATION OF THE STUDY AREA}

The abandoned Podwiśniówka mine pit is located in the easternmost part of the dismembered Wiśniówka massif of the western Holy Cross Mountains. Along with the operative Wiśniówka Duża and inoperative Wiśniówka Mała quarries, this is a part of a larger mining field (Fig. 1). The entire area is situated within Upper Cambrian (Furongian) series composed of quartzites, quartzitic sandstones, in places with siltstone, clayey shale, tuffite and bentonite interbeds (e.g., Żylińska et al. 2006). The Podwiśniówka mine pit is partly infilled with acidic water forming a shallow pond about $1.5 \mathrm{~m}$ deep (Migaszewski et al. 2007). The characteristic feature of the landscape is a towering wall composed of three exposed rock series (Fig. 2A). The southern series consists of light gray-to-white, fine-bedded quartzites with numerous tuffite and bentonite interbeds dipping northward. The central series is made of gray-to-dark gray, steep-dipped, medium-bedded quartzites, locally quartzitic sandstones and siltstones, with subordinate carbonaceous clayey shale interbeds (Fig. 2B, C). In contrast to the tuff-bearing series, these rocks are highlighted by the presence of scattered and veined crypto- to microcrystalline pyrite associated with secondary goethite accumulations. In some places, quartzitic-quartz-pyrite breccias occur. Some of the quartz-pyrite veins and veinlets are partly covered with white-to-brown wavellite and greenish variscite. The joint and fracture planes of the quartzites are veneered with white, green and brown-red efflorescences of hydrothermal minerals, including nacrite and jarosite 
(study in progress). The pyrite-bearing zone trends eastward through the pit floor to the opposite pit wall. The northern series is composed of light gray-to-brown-red nonbedded hematite-goethite quartzites (Fig. 2D), passing northward into white hydrothermal metamorphic quartzites, locally quartzitic-quartz breccias.

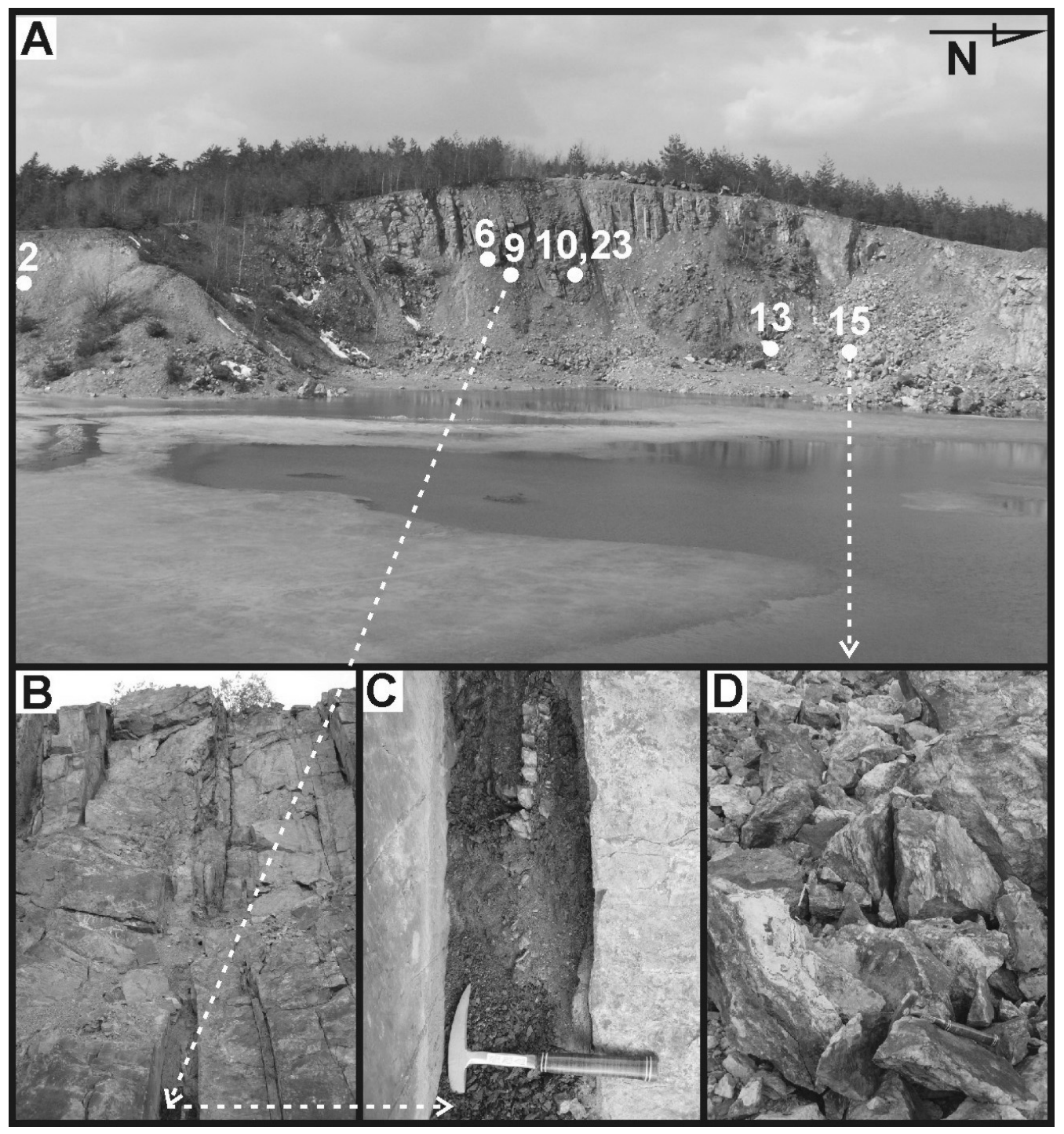

Fig. 2. (A) A view of the western wall of the Podwiśniówka mine pit with a quartzite-carbonaceous clayey shale series containing quartz-pyrite mineralization (central part of the wall), a quartzite-tuff-bentonite series in southern part (left photo margin) and a tectonically brecciated quartzite series with hematite/goethite mineralization in northern part (right photo side).

Selected sampling points 2, 6, 9, 10, 10a, 13, 15 (see Figs. 3A-F, 4A-F, 5); (B) (C) gorceixite-bearing carbonaceous clayey shale interbed (sample 9); (D) iron-bearing quartzites (sample 15) 


\section{MATERIALS AND METHODS}

Microscopic examinations were performed on quartzite, clayey shale, tuff and pyrite-quartz samples (Fig. 2A-D) using conventional optical methods in transmitting and reflected light (polarized microscope Axiolab Carl Zeiss). In addition, the study of these rocks was carried out with scanning electron microscopy (SEM; microscope LEO 1430; signal A = SE1, magn. = 158-35,120 $\times$, EHT = $15.00 \mathrm{kV}, \mathrm{WD}=8-24 \mathrm{~mm}$ ) using various techniques (SEI, QBSD, CL, EDX). The SEM study was performed at the Electron Microscope Laboratory of the Polish Geological Institute in Warsaw. Semi-quantitative chemical analyses of selected minerals were made with an EDS ISIS Detector (Oxford Instruments Ltd.). In addition, identification of mineral phases was done with X-ray diffraction (XRD; diffractometer Philips X'Pert PW 3020) using Ka wavelengths $1.54056 \AA$ A.

For the purpose of this study the selected quartzite, clayey shale, tuff and pyrite-quartz bulk samples were analysed for 23 major and trace elements (detection limits expressed as $\mathrm{mg} \cdot \mathrm{kg}^{-1}$ are given in parentheses), i.e. Al (50), As (3), Ba (10), Ca (50), $\mathrm{Cd}$ (3), $\mathrm{Co}$ (3), Cr (3), Cu (5), Fe (100), K (50), Mg (100), Mn (10), Mo (2), Na (100), Ni (5), $\mathrm{P}(50), \mathrm{Pb}(3), \mathrm{Sr}(2), \mathrm{Ti}(10), \mathrm{V}(5)$ and $\mathrm{Zn}(2)$, using X-ray fluorescence spectrometry (XRF; spectrometer Philips PW 2400). In addition, $\mathrm{Hg}$ was determined using the atomic absorption spectroscopic method (AAS; Altec amalgam analyzer AMA 254). These samples were also analysed for 13 REE (La, Ce, Pr, Nd, Sm, Eu, Gd, Tb, Dy, Ho, Er, Tm, $\mathrm{Yb})^{1}$, Th, U, Y and Zr using inductively coupled plasma mass spectrometry (ICP-MS; spectrometer ELAN DRC II, Perkin Elmer). The XRD and chemical analyses were performed in the accredited Central Chemical Laboratory of the Polish Geological Institute in Warsaw.

\section{RESULTS AND DISCUSSION}

Petrographic studies of the gorceixite-bearing host rocks in the Podwiśniówka quarry indicate that quartz and muscovite are predominant rock-forming minerals of the tuffs, clayey shales and quartzites. Most of the clayey shales contain a considerable amount of aleuritic terrigenous and volcanogenic quartz grains. Smectite, kaolinite and pyrite (including As-rich variety) are subordinate, whereas chalcedony and feldspars occur only in trace amounts. Accessory minerals are represented primarily by rutile and zircon commonly with pyramidal, dentate overgrowths of xenotime, and scarce monazite and tourmaline. Some of these minerals are depicted in Figure 3E. No apatite has been recorded in the rocks examined. Except for the tuffs, all the remaining rocks contain variable amounts of scattered and veined pyrite, as well as a large variety of supergene minerals, including goethite, iron sulphates, and subordinate secondary jarosite and gypsum (study in progress).

\footnotetext{
1 Lu was used as an internal reference material for determining REE. Pm was not determined.
} 
The gorceixite occurs in all the rock series examined, primarily in form of scattered anhedral grains or granular aggregates varying in size between about 0.5 and $100 \mu \mathrm{m}$. In general, these tiny accumulations infill voids, cavities, cracks and partly fissures (Figs 3A-F, 4A-D). Sub- or euhedral grains lining vugs are scarce (Fig. 3A, B). The largest accumulations of gorceixite have been noted in the carbonaceous clayey shale interbed (sample 9). This mineral forms intergrowths in an aleuropelitic hydromusco-

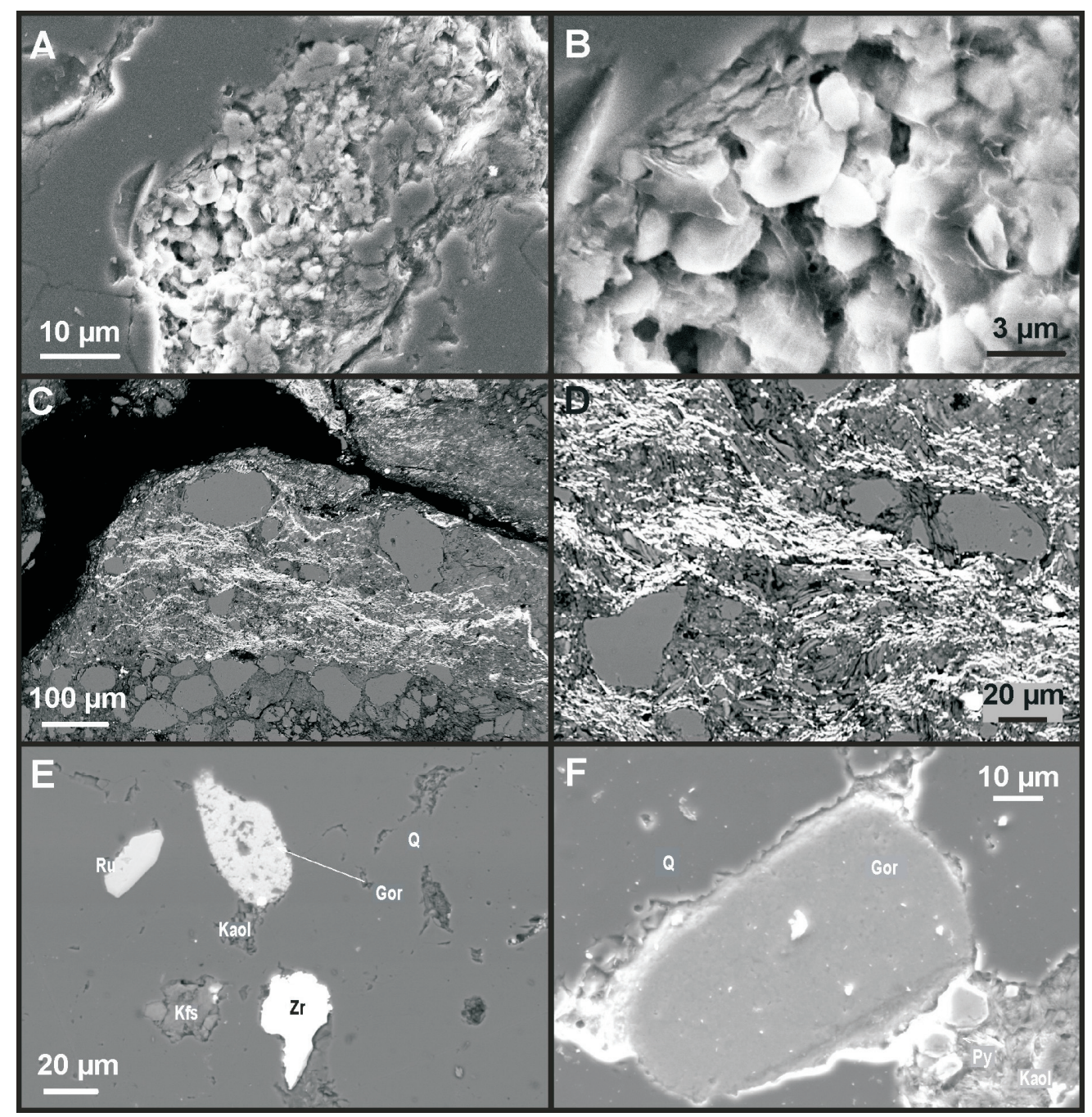

Fig. 3. SEM images: (A, B) Vug filling composed of pseudocubic crystals of gorceixite growing in a cavity of aleuropelitic hydromuscovite (illite-2 $\mathrm{M}_{1}$ )-quartz matrix (sample 6); (C, D) Accumulations of authigenic gorceixite at different scales in an aleuropelitic hydromuscovite (illite-2 $\mathrm{M}_{1}$ )-quartz groundmass (sample 9); (E) Grains/accumulations of gorceixite (Gor) with minute rutile inclusions (white), rutile (Ru), zircon (Zr), K-feldspar (Kfs) and kaolinite (Kaol) in a quartz groundmass (Q) of quartzite (sample 10);

(F) Gorceixite (Gorc) and pyrite (Py) grains and kaolinite (nacrite?) accumulations (Kaol) filling a vug in a quartzite (sample 10) 
vite (illite-2 $\mathrm{M}_{1}$ )-quartz groundmass, exceeding $1 \mathrm{~mm}$ in length (Figs $3 \mathrm{C}, \mathrm{D}, 4 \mathrm{~F}$ ). Some of the gorceixite grains contain inclusions of rutile reaching $5 \mu \mathrm{m}$ in size (Fig. 3E). The gorceixite is scarce in the hydrothermal quartz-pyrite veins (Fig. 4D). This is probably due to the very low concentrations of $\mathrm{Al}, \mathrm{Ba}$ and $\mathrm{P}$ both in the quartz and pyrite (sample 10a in Table 2). It is interesting to note that the gorceixite forms paragenetic accumulations with the nacrite, a typical hydrothermal mineral lining numerous fissures in the quartzites (study in progress).

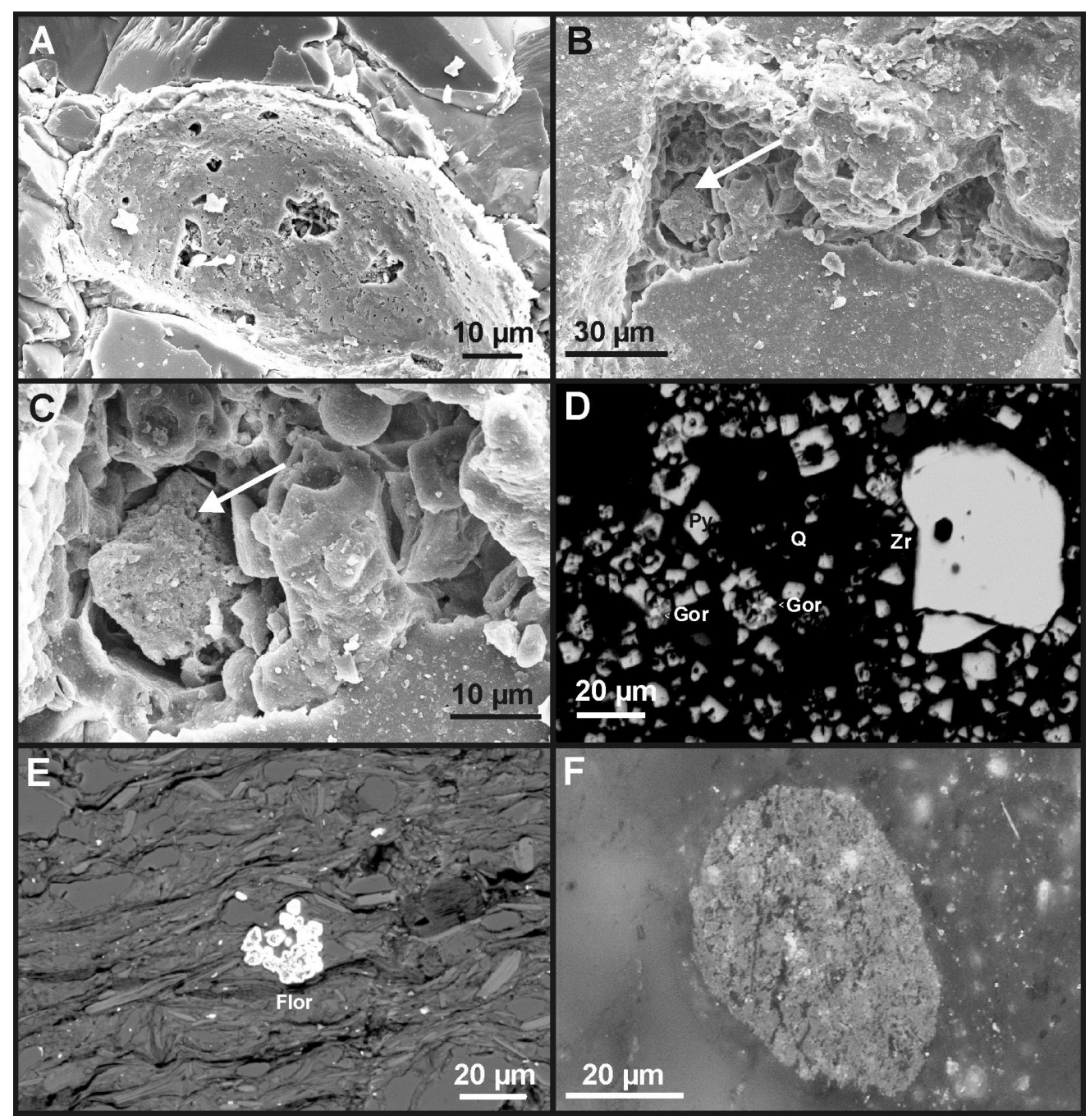

Fig. 4. SEM images: (A) Gorceixite grain in a ferric quartzite (sample 15); (B, C) Gorceixite grain (arrow) at different scales and a spheric cyst in a quartzite void (sample 10); (D) Pyrite (Py) and subordinate gorceixite (Gor) grains in a veined quartz matrix $(\mathrm{Q})$; cracked zircon grain on the right photo side $(\mathrm{Zr})$ (sample 10a); (E) Framboidal aggregates of florencite (Flor) in an aleuropelitic quartz-muscovite groundmass of tuff (sample 2); Optical microscope image: (F) Gorceixite grain in an aleuropelitic hydromuscovite (illite-2 $\mathrm{M}_{1}$ )-quartz groundmass; transmitted light, partly crossed nicols (sample 9) 
The EDS spectrum of gorceixite confirmed the presence of the main elements making up this mineral, i.e. $\mathrm{Al}, \mathrm{Ba}, \mathrm{O}$ and $\mathrm{P}$ (Fig. 5A). Of the related isostructural minerals (crandallite series), Ce-bearing goyazite (Fig. 5B) and REE-bearing-florencite (Figs 4E, 5C) have been recorded in trace amounts in the tuff and quartzite. However, this issue should be further examined due to the small number of samples analysed by the XRD/EDS and XRD methods.
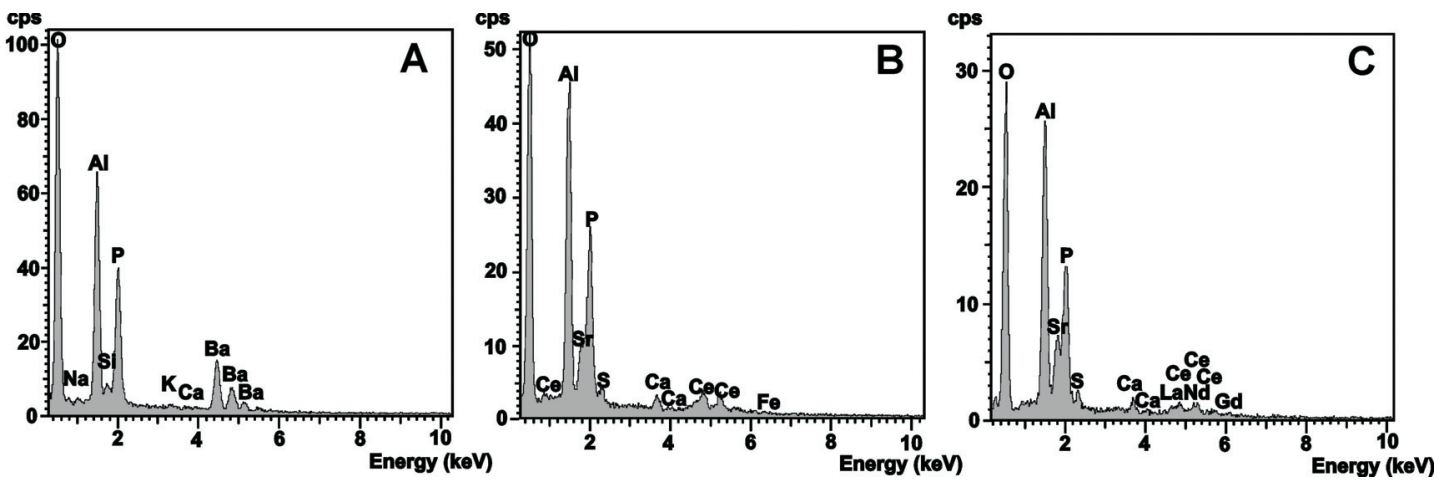

Fig. 5. Spectra of: (A) gorceixite, (B) Ce-bearing goyazite, and (C) REE-bearing florencite; $c p s=$ counts per second. (A) and (C) from sample 2 and (B) from sample 10a (see Fig. 2)

The results of major and trace element determinations of the selected bulk rock and pyrite samples are presented in Table 1. Compared to the non-ferric quartzite, quartz and pyrite, the tuff and carbonaceous clayey shales reveal distinctly higher concentrations of $\mathrm{Al}, \mathrm{Ba}, \mathrm{Cr}, \mathrm{K}, \mathrm{Mg}, \mathrm{Na}, \mathrm{P}, \mathrm{Ti}, \mathrm{V}, \mathrm{Zr}$, and partly $\mathrm{Ca}$ and $\mathrm{Sr}$. In contrast, the Fe-quartzite exhibits high concentrations of $\mathrm{Fe}, \mathrm{P}$ and $\mathrm{Sr}$, and intermediate concentrations of $\mathrm{Ba}$ and $\mathrm{Cr}$. Except for $\mathrm{Cr}$ and $\mathrm{V}$, these elements make up the rock-forming or accessory minerals. No barite or $\mathrm{Cr}$ and $\mathrm{V}$ minerals have been noted in the Podwiśniówka rocks (see also Migaszewski et al. 2007). The gorceixite seems to be the only $\mathrm{Ba}$ mineral in the profile examined. $\mathrm{As}, \mathrm{Cd}, \mathrm{Hg}$ and at least partly $\mathrm{Co}, \mathrm{Cu}$ and $\mathrm{Ni}$ are linked to the pyrite and some of its secondary minerals (e.g., goethite).

Compared to the pyrite and quartzites, the tuff and clayey shales exhibit noticeably higher levels of REE (255.52-455.09 vs. 50.82-112.86 mg. $\left.\mathrm{kg}^{-1}\right)$, Th (17.8-35.6 vs. $\left.2.2-5.9 \mathrm{mg} \cdot \mathrm{kg}^{-1}\right), \mathrm{U}\left(4.24-7.86\right.$ vs. $\left.0.42-1.64 \mathrm{mg} \cdot \mathrm{kg}^{-1}\right)$ and $\mathrm{Y}\left(13.9-31.8\right.$ vs. $\left.2.7-5.4 \mathrm{mg} \cdot \mathrm{kg}^{-1}\right)$ (Table 2). The highest concentrations of gorceixite, REE as well as Th, $U$ and $Y$ were noted in the carbonaceous clayey shale interbed (sample 9) (Fig. 3C,D, Table 2). Except for the crandallite series minerals, the principal scavengers of REE, Th and $U$ are zircon, xenotime and monazite. Of these elements, the trivalent REE can exchange directly with $\mathrm{Y}^{3+}$ in the xenotime with no charge-compensating species necessary as is the case with $\mathrm{Zr}^{4+}$ in the zircon (Cherniak 2006). The total REE levels in the rocks of the Podwiśniówka area are in the range of those (150.2-582.2 mg. $\left.\mathrm{kg}^{-1}\right)$ recorded in kaolinitic clays of Waldsaum open pit, Germany (Dill et al. 1995) and close to the average REE content $\left(451 \mathrm{mg} \cdot \mathrm{kg}^{-1}\right)$ in the parent rocks of apatite-rich carbonatites of Brazil (Walter et al. 1995). 


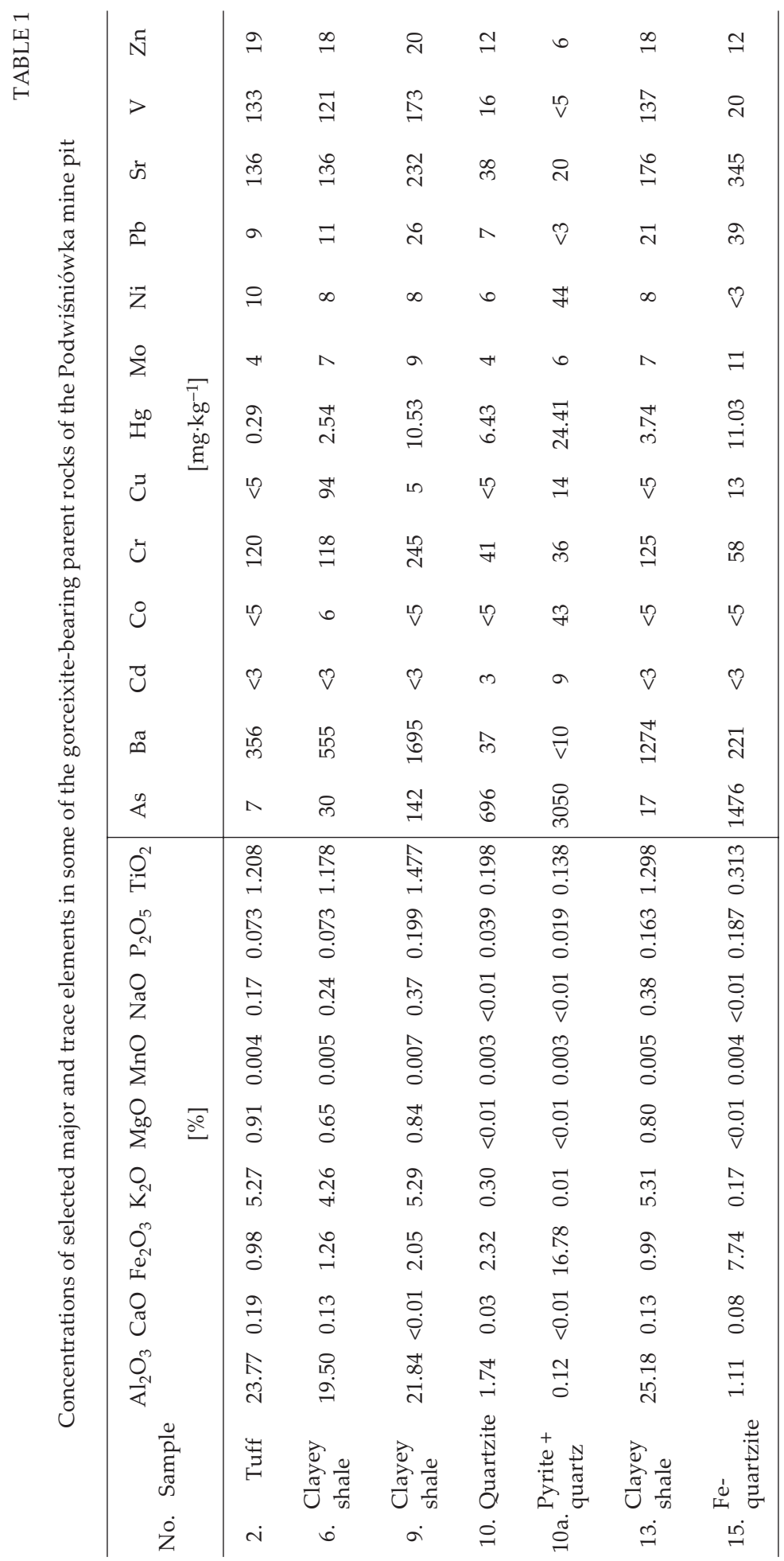

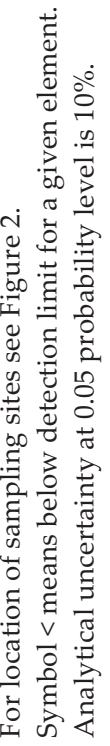




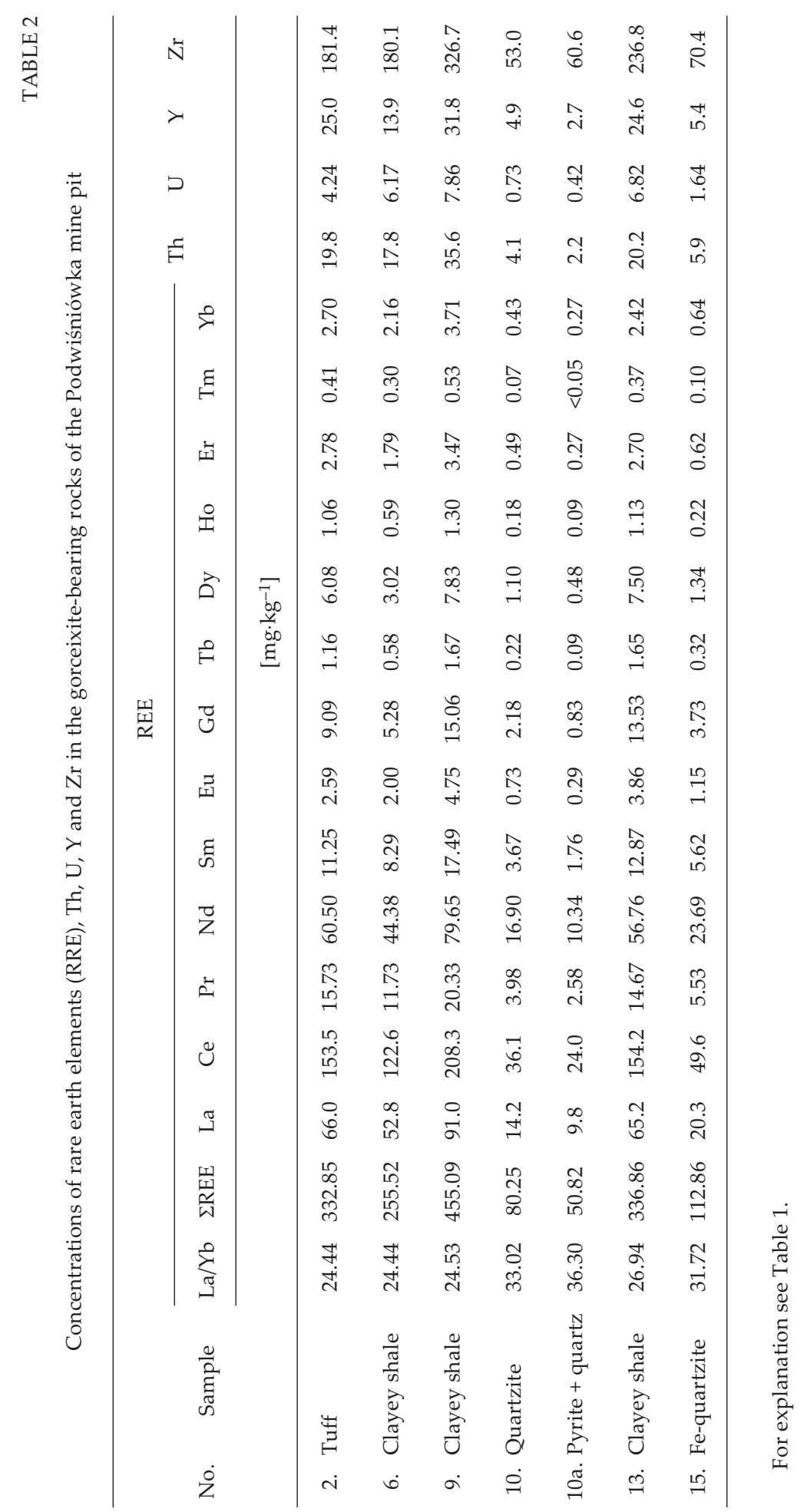


In addition, the tuff and clayey shales are characterized by an increased amount of LREE (La through Eu or Gd) of larger ionic radii relative to the HREE, showing the following sequence: $\mathrm{Ce}>\mathrm{La}>\mathrm{Nd}>\mathrm{Pr}$. The LREE enrichment of the gorceixite host rocks is evidenced by a high $\mathrm{La} / \mathrm{Yb}$ ratio varying from 24.44 (shales and tuffs) to 36.30 (pyrite with an admixture of quartz) (Table 2). This ratio is higher compared to that (8.65) recorded in the parent rocks of apatite-rich carbonatites of Brazil (Walter et al. 1995). According to Rasmussen et al. (1998), the apatite and aluminophosphates are enriched in light REE, whereas xenotime concentrates heavy REE.

When considering the origin of the gorceixite of the Podwiśniówka area, the question arises whether this mineral formed as a result of hypogene alterations (including submarine wearhering) or supergene processes. However, it should be stressed that no matter what hypothesis is considered, the principal issue is the source of $\mathrm{Al}, \mathrm{Ba}, \mathrm{P}$ and REE, the elements which are essential for precipitation of gorceixite. The formation of gorceixite and other aluminophosphate and phosphate minerals requires a low $\mathrm{pH}$ and high concentrations of dissolved phosphates (Nriagu 1976; Stoffregen, Alpers 1987). The lack of $\mathrm{SO}_{4}{ }^{2-}$ - and $\mathrm{AsO}_{4}{ }^{3-}$-bearing APS minerals, e.g., svanbergite, woodhouseite, kemmlitzite, arsenocrandallite, dussertite (Dill 2001), in the Podwiśniówka area precludes As-rich pyrite weathering as a decisive factor triggering the formation of gorceixite (Eary 1999). The main source of Ba for this mineral may be carbonaceous clayey shales and volcaniclastics (Dill et al. 1995; Dill 2001). Al in turn may be derived from degrading muscovite, clay minerals and feldspars, whereas $\mathrm{P}$ and REE primarily from organically-coated clay minerals or volcanic ashes (Dill 2001 and references therein). If the gorceixite precipitates in a shallow-marine basin, these adsorbed elements may be released to sediment pore water during bacterially induced decomposition of organic matter and reduction of Fe oxyhydroxides (Rasmussen 1996). However, there is still uncertainty on the provenance of the REE due to their scarcity ( 1 to $6.5 \mu \mathrm{g} \cdot \mathrm{kg}^{-1}$ ) in the ocean water (Elderfield, Greaves 1982). In contrast, the river waters exhibit much higher concentrations of REE varying from 47.5 to $192 \mu \mathrm{g} \cdot \mathrm{kg}^{-1}$ (e.g., Martin et al. 1976; Elderfield et al. 1990). Although the sulphate reduction zone (below the sediment-water interface) may exhibit the 10-to-50 higher levels of REE (Elderfield, Sholkovitz 1987), this evidence does not explain distinctly raised concentrations of these elements in the rocks examined.

The microscopic study indicates that the gorceixite precipitated and crystallized in shallow-marine sediments at the early-diagenetic stage. This is evidenced by occurrences of gorceixite in quartzite vugs, cavities and cracks (Figs 3A, B, E, F, 4A-D) as well as by authigenic intergrowths of this mineral in an aleuropelitic hydromuscovite-quartz groundmass of the carbonaceous clayey shales (Fig. 3C, D). The coexistence of gorceixite with the veined nacrite or pyrite mineralization and tuffs/bentonites, as well as the microtextural features and distinctly raised levels of REE in the gorceixite-rich parent rocks suggest that a more complex model should be chosen when considering the origin of this mineral in the Podwiśniówka area. The lack of nacrite and pyrite signature in the tuff/bentonite-bearing series indicates that the main source of $\mathrm{Ba}, \mathrm{Al}, \mathrm{P}$ and LREE for gorceixite was the volcaniclastic material. However, the nacrite crystallizes at temperatures of about 200 to $300^{\circ} \mathrm{C}$, which indicates that the gorceixite of the pyrite 
and at least partly hematite/goethite series was a product of hydrothermal vent activity in the shallow-marine environment. The hot spring fluids apparently discharged $\mathrm{Ba}$, $\mathrm{Al}, \mathrm{P}$ and LREE to the sediment and water column, overprinting other possible sources of these elements, i.e. carbonaceous clayey sediments and volcaniclastic material.

\section{CONCLUSIONS}

From this study the following conclusions can be drawn:

1. The gorceixite is a predominant mineral of the crandallite series found in the Podwiśniówka mine pit. Florencite and goyazite are scarce.

2. The carbonaceous clayey shales of the Podwiśniówka area are characterized by a high amount of the gorceixite and REE. This evidence indicates that clay minerals may have acted as Ba, $\mathrm{P}$ and REE traps.

3. The presence of paragenetically linked pyrite and nacrite, and in places volcaniclastic material, as well as the microtextural features and markedly raised levels of REE suggest that the gorceixite is a product of both submarine hot springs and volcanic activity. The LREE-rich hydrothermal fluids may have overprinted other sources of $\mathrm{Al}, \mathrm{Ba}, \mathrm{P}$ and REE.

4. The precipitation and crystallization of gorceixite occurred in the shallow-marine basin apparently during the late Cambrian.

Another question that requires further studying is the temporal relationship between the crandallite series and the remaining phosphate minerals, i.e. xenotime, wavellite and variscite as well as quartz-pyrite mineralization. The results obtained provide a reference level for a future study on the location of the potential source of some elements for the gorceixite and other related minerals.

Acknowledgements. We thank Irena Budzyk, Dariusz Lech, Wanda Narkiewicz of the Central Chemical Laboratory of the Polish Geological Institute in Warsaw for performing XRF, ICP-MS, AAS and XRD analyses. This study was supported as a research grant by the Ministry of Science and Higher Education (No. 2 P04G 041 30).

\section{REFERENCES}

CABAŁA J., 2001: Mineral composition and chemical characteristics of ecological halloysitic raw materials from Dunino (Lower Silesia). Zeszyty Naukowe Politechniki Śląskiej, Górnictwo 248, 33-40 (in Polish with English abstract).

CHERNIAK D.J., 2006: $\mathrm{Pb}$ and rare earth element diffusion in xenotime. Lithos, 88, 1-14.

DILL H.G., 2001: The geology of aluminium phosphates and sulphates of the alunite group minerals: a review. Earth-Science Reviews 53, 35-93.

DILL H.G., FRICKE A., HENNING K.H., 1995: The origin of Ba- and REE-bearing aluminium-phosphate-sulphate minerals from the Lohrheim kaolinitic clay deposit (Rheinisches Schiefergebirge, Germany). Applied Clay Science 10, 231-235.

DILL H.G., MELCHER F., FÜßL M., WEBER B., 2006: Accessory minerals in cassiterite: A tool for provenance and environmental analyses of colluvial-fluvial placer deposits (NE Bavaria, Germany). Sedimentary Geology 191, 171-189. 
DUMAŃSKA-SŁOWIK M., HEFLIK W., NATKANIEC-NOWAK, SIKORSKA M., 2007: Wawellit i waryscyt w piaskowcach kambryjskich z kamieniołomu Wiśniówka Duża koło Kielc (Wavellite and variscite in the Cambrian sandstones from the Wiśniówka Duża quarry near Kielce). Przegląd Geologiczny 4, 287 (in Polish)

EARY L.E., 1999: Geochemical and equilibrium trends in mine pit lakes. Applied Geochemistry 14, $963-987$.

ELDERFIELD H., GREAVES M.J., 1982: The rare earth elements in sea water. Nature 296, 214-219.

ELDERFIELD H., SHOLKOVITZ E.R., 1987: Rare earth elements in the pore waters of reducing nearshore sediments. Earth and Planetary Science Letters 82, 280-288.

ELDERFIELD H., UPSTILL-GODDARD R., SHOLKOVITZ E.R., 1990: The rare earth elements in rivers, estuaries, and coastal seas and their significance to the composition of ocean waters. Geochimica et Cosmochimica Acta 54, 971-991.

FINKELMAN R.B., STANTON R.W., 1978: Identification and significance of accessory minerals from a bituminous coal. Fuel 57, 763-768.

JERDEN J.L., SINHA A.K., 2006: Geochemical coupling of uranium and phosphorus in overlying an unmined uranium deposit: Coles Hill, Virginia. Journal of Geochemical Exploration 91, 56-70.

KATO T., RADOSLOVICH E.W., 1968: Crystal structure of soil phosphates. Transactions of the $9^{\text {th }}$ International Congress of Soil Science, Adelaide, 2, 725-731.

KOWALSKI W., ŚMIETAŃSKA I., 1983: Gorceixite from a barite-fluorite deposit at Stanisławów (Kaczawskie Mts). Mineralogia Polonica 13, 1, 3-16.

MANECKI A. 2004: Encyclopedia of minerals: Minerals of earth and cosmic matter. AGH, Uczelniane Wydawnictwo Naukowo-Dydaktyczne. Kraków.

MARTIN J.M., Ȟ̌GDAHL O., PHILLPOTT J.C., 1976: Rare earth element supply to the ocean. Journal of Geophysical Research 81, 3119-3124.

MIGASZEWSKI Z.M., GAŁUSZKA A., PASŁAWSKI P., STARNAWSKA E., 2007: An influence of pyrite oxidation on generation of unique acid pit water: A case study, Podwiśniówka quarry, Holy Cross Mountains (south-central Poland). Polish Journal of Environmental Studies 16 (3), 407-421.

MIGASZEWSKI Z.M., GAŁUSZKA A., HAŁAS S., DĄBEK J., DOŁĘGOWSKA S., PASŁAWSKI P., STARNAWSKA E., MICHALIK A., 2008: Chemical and isotopic variations in the Wiśniówka Mała mine pit water, Holy Cross Mountains (south-central Poland). Environmental Geology (DOI 10.1007/s00254-008-1279-z).

NRIAGU J.O., 1976: Phosphate - clay mineral relations in soils and sediments. Canadian Journal of Earth Science 13, 717-736.

POULIOT A., HOFMANN H.J., 1981: Florencite: first occurrence in Canada. Canadian Mineralogist 19, 535-540.

PUTTER T.D., ANDRE L., BERNARD A., DUPUIS C., JEDWAB J., NICAISE D., PERRUCHOT A., 2002: Trace element (Th, U, Pb, REE) behavior in a cryptokarstic halloysite and kaolinite deposit from Southern Belgium: importance of "accessory" mineral formation for radioactive pollutant trapping. Applied Geochemistry 17, 1313-1328.

RASMUSSEN B., 1996: Early-diagenetic REE-phosphate minerals (florencite, crandallite, gorceixite and xenotime) in marine sandstones: A major sink for oceanic phosphorus. American Journal of Science 296, 601-632.

RASMUSSEN B., BUICK B., TAYLOR W.R., 1998: Removal of oceanic REE by authigenic precipitation of phosphatic minerals. Earth and Planetary Science Letters 164, 135-149.

RIBEIRO C.C., BROD J.A., JUNQUEIRA-BROD T.C., GASPAR J.C., PETRINOVIC I.A., 2005: Mineralogical and field aspects of magma fragmentation deposits in a carbonate-phosphate magma chamber: evidence from the Catalăo I complex, Brazil. Journal of South American Earth Sciences 18, 355-369.

SCOTT K.M., 1987: Solid solution in, and classification of gossan-derived members of the alunite-jarosite family, Northwest Queensland, Australia. American Mineralogist 72, 178-187.

STOFFREGEN R.F., ALPERS C.N., 1987: Woodhouseite and svanbergite in hydrothermal ore deposits: product of apatite destruction during advanced argillic alteration. Canadian Mineralogist 25, 201-211.

WALTER A.V., NAHON D., FLICOTEAUX R., GIRARD J.P., MELFI A., 1995: Behaviour of major and trace elements and fractionation of REE under tropical weathering of a typical apatite-rich carbonatite from Brazil. Earth and Planetary Science Letters 136, 591-602. 
WARD C.R., CORCORAN J.F., SAXBY J.D., READ H.W., 1996: Occurrence of phosphate minerals in Australian coal seams. International Journal of Coal Geology 30, 185-210.

WISE W.S., 1975: Solid solution between the alunite, woodhouseite, and crandallite mineral series. Neues Jahrbuch für Mineralogie. Monatshefte 12, 540-545.

ŻYLIŃSKA A., SZCZEPANIK Z., SALWA S., 2006: Cambrian of the Holy Cross Mountains, Poland: biostratigraphy of the Wiśniówka Hill succession. Acta Geologica Polonica 56 (4), 443-461.

Zdzisław M. MIGASZEWSKI, Ewa STARNAWSKA, Agnieszka GAŁUSZKA

\section{Gorceixyt w utworach kambru górnego w kamieniołomie Podwiśniówka, Góry Świętokrzyskie (południowo-centralna Polska)}

\section{Streszczenie}

Niniejszy artykuł przedstawia wyniki badań petrograficznych, mineralogicznych (SEM/EDS, XRD) i geochemicznych (XRF, AAS, ICP-MS) gorceixytu $\mathrm{BaAl}_{3} \mathrm{H}\left[(\mathrm{OH})_{6}\left(\mathrm{PO}_{4}\right)_{2}\right]$ z nieczynnego kamieniołomu Podwiśniówka. Wyrobisko to częściowo wypełnia zbiornik wodny o bardzo niskim $\mathrm{pH}$, którego chemizm pozostaje pod silnym wpływem odsłoniętej strefy mineralizacji pirytowej. Gorceixyt występuje w górnokambryjskich łupkach ilastych, kwarcytach i tufach w postaci drobnych skupień o średnicy od około 0,5 do $100 \mu \mathrm{m}$. Wypełniają one pory, próżnie, spękania i częściowo szczeliny w skałach. Pozostałe minerały z grupy crandallitu (florencyt i goyazyt) występują w ilościach śladowych. Skały wzbogacone w gorceixyt, a w szczególności węgliste łupki ilaste, wyróżniają się najwyższą zawartością pierwiastków ziem rzadkich, dochodzącą do $455,09 \mathrm{mg} \cdot \mathrm{kg}^{-1}$. W porównaniu z podobnymi stanowiskami na świecie, skały zawierające gorceixyt $\mathrm{z}$ kamieniołomu Podwiśniówka są wyraźnie bogatsze w lżejsze pierwiastki ziem rzadkich, wykazując stosunek La/Yb w zakresie od 24,44 do 36,30. Gorceixyt występuje miejscami w postaci paragenetycznych skupień z żyłowym pirytem i nakrytem. Ostatni z wymienionych minerałów jest wskaźnikiem średnich i wysokich temperatur krystalizacji. Współwystępowanie z nakrytem i pirytem, cechy mikroteksturalne oraz wysokie zawartości pierwiastków ziem rzadkich świadczą o genezie gorceixytu i pozostałych minerałów z grupy crandallitu z Podwiśniówki. Powstały one przypuszczalnie $\mathrm{w}$ wyniku działalności hydrotermalnej $\mathrm{w}$ płytkim basenie morskim w późnym kambrze. Należy jednak podkreślić, że działalność roztworów hydrotermalnych mogła zamaskować inne możliwości pochodzenia Al, Ba, P i pierwiastków ziem rzadkich. W szczególności pierwiastki te mogą być związane z działalnością wulkaniczną, której przejawy w postaci wkładek tufów i bentonitów występują w najstarszej serii skalnej odsłaniającej się w kamieniołomie. 